PAPER

\title{
Is hypertension a more frequent risk factor for deep than for lobar supratentorial intracerebral haemorrhage?
}

\author{
C A Jackson, C L M Sudlow
}

See end of article for authors' affiliations ....................

Correspondence to: C A Jackson, Division of Clinical Neurosciences, University of Edinburgh, Western General Hospital, Bramwell Dott Building, Edinburgh EH4 2XU, UK; caroline.jackson@ed.ac.uk

Received 24 January 2006 Revised version received 21 April 2006

Accepted 21 April 2006

Published Online First 11 May 2006
Objective: To determine whether evidence from observational studies supports the widely held belief that hypertension is more commonly a risk factor for deep than for lobar supratentorial intracerebral haemorrhage.

Methods: Studies comparing the frequency of hypertension as a risk factor for deep versus lobar supratentorial intracerebral haemorrhage, excluding haemorrhages with identified secondary causes, were identified and subjected to a meta-analysis. The effects of predefined methodological quality criteria on the results were assessed and other sources of bias were considered.

Results: The pooled result from all 28 included studies (about 4000 patients) found hypertension to be about twice as common in patients with deep as in those with lobar haemorrhage (odds ratio (OR) 2.10, $95 \%$ confidence interval $(95 \% \mathrm{Cl}) 1.82$ to 2.42$)$, but there was significant heterogeneity between studies. The pooled OR was less extreme for studies that used a pre-stroke definition of hypertension, were population based or included first-ever strokes only. In the three studies meeting all criteria (601 patients), deep haemorrhage was associated with a smaller, statistically significant excess of hypertension (OR 1.50, $95 \% \mathrm{Cl} 1.09$ to 2.07 ). The OR for studies confined to younger patients seemed to be more extreme (12.32, $95 \% \mathrm{Cl} 6.13$ to 24.77 ), but none of these studies fulfilled our methodological quality criteria. Additional, unquantified sources of bias included uncertainty about whether those doctors reporting brain scans were blind to hypertension status, uncertain reliability of the classification of haemorrhage location and variable rates of investigation for secondary causes.

Conclusions: An excess of hypertension was found in patients with deep versus lobar intracerebral haemorrhages without an identified secondary cause, but this may be due to residual, unquantified methodological biases.
I ntracerebral haemorrhage can have several causes. In younger patients ( $<40$ years), intracranial vascular malformations are the most common single cause of intracerebral haemorrhage, usually lobar in location. ${ }^{1}$ Cerebral amyloid angiopathy is thought to underlie about 30\% of intracerebral haemorrhages in those aged $>70$ years and to cause mainly lobar haemorrhages. ${ }^{1}$ Although hypertension is a major risk factor for intracerebral haemorrhage in general, ${ }^{2-8}$ it is commonly considered to be associated more with patients having deep than with those having lobar haemorrhage. The current understanding of the arterial pathology underlying deep haemorrhage is largely based on studies conducted in the 1960s and 1970s by Fisher and others, with the meticulous examination and description of brains examined on autopsy of people with and without an intracerebral haemorrhage as the cause of their death. ${ }^{9-13}$ Fisher's findings led him to propose that hypertensive lipohyalinosis, affecting the small, deep, perforating, intracranial blood vessels, may lead to lacunar infarction in some circumstances and to deep intracerebral haemorrhage in others. ${ }^{11}{ }^{12}$ These conclusions, however, were based on small numbers (his own studies included $<30$ patients in total); the subjects in autopsy studies were sometimes deemed hypertensive or not on the basis of blood pressure soon after stroke, and uncertainty remains about whether the vascular pathology Fisher observed preceded or resulted from haemorrhage. Furthermore, lipohyalinotic changes have been found in the brains of normotensive patients with recent intracerebral haemorrhage. ${ }^{14}$ Despite these limitations, Fisher's theory of the hypertensive arterial pathology of deep intracerebral haemorrhage has become so entrenched in the literature and in clinical teaching and practice ${ }^{15-17}$ that deep haemorrhage has become virtually synonymous with hypertensive haemorrhage.

But is hypertension really more commonly a risk factor for patients with deep haemorrhage than for those with lobar haemorrhage? In this paper, we report the findings of a systematic review and meta-analysis of studies that compared the frequency of hypertension as a risk factor for patients with deep haemorrhage versus those with lobar supratentorial haemorrhage, and consider the effects of study methodology on the results.

\section{METHODS}

\section{Study identification}

We sought studies on patients with intracerebral haemorrhage, confirmed after brain imaging or after postmortem examination, published between January 1966 and December 2004 (inclusive), which provided data on the frequency of hypertension in patients with deep haemorrhage versus those with lobar supratentorial intracerebral haemorrhage. We did not exclude otherwise eligible studies that grouped deep supratentorial and posterior fossa haemorrhages together, as the proportion of such studies was small.

We identified studies with a comprehensive electronic search strategy (see appendix), supplemented by searching through the reference lists of all relevant articles identified; our own and colleagues' collections of papers on intracerebral haemorrhage; and textbooks on stroke. 


\section{Data extraction}

We extracted data from included studies on the total number and source of the patients studied; the numbers with deep or lobar haemorrhage, before and after any exclusions; the numbers with hypertension as a risk factor in each of the groups with deep and lobar haemorrhage; the mean (or median) age of the patient in each group; the definitions of deep and lobar haemorrhage and of hypertension; and whether the study population included first-ever strokes only. Where possible, to reduce noise in our analyses, we excluded patients with haemorrhage due to identified secondary causes unrelated to prior hypertension (such as intracranial vascular malformation, blood dyscrasia, anticoagulant treatment or drug misuse).

As the location of the bleeding source for some large haemorrhages is unclear from the brain scan, their classification as deep or lobar is potentially subject to various sources of bias. We therefore also extracted any available information on the type (computed tomography or magnetic resonance imaging) and timing of diagnostic brain scans; whether any haemorrhages were considered to be unclassifiable; whether brain scans were reported blinded to hypertension status; who reported or reviewed the scans (neuroradiologist, neurologist, etc); and the intrarater and inter-rater reliability of the classification of haemorrhage location.

\section{Statistical analyses}

We calculated study-specific and summary odds ratios (ORs) of hypertension in patients with deep versus lobar haemorrhage using Cochrane Revman V.4.2. ${ }^{18}$ We carried out several sensitivity subgroup analyses, comparing the results from studies that clearly fulfilled each of several predefined methodological quality criteria with studies that did not. These were as follows:

1. A definition of hypertension based solely on raised blood pressure before stroke (as blood pressure is often raised after intracerebral haemorrhage, so that blood pressure after stroke does not necessarily reflect that before stroke)

2. A population-based study, which we defined as being either community based or hospital based, where the hospital was the only centre serving a defined population and all admissions with intracerebral haemorrhage were included

3. Inclusion of patients with first-ever stroke only (as risk factors and the distribution of deep and lobar haemorrhage may differ between the first and recurrent strokes).

We then compared results from studies that met all three methodological quality criteria with those that did not.

In a retrospective subgroup analysis, we compared results from studies recruiting people unselected for age against those specifically recruiting younger patients. We used the $\chi^{2}$ test to assess statistical heterogeneity between studies and groups of studies.

\section{RESULTS}

\section{Study characteristics}

We found 32 potentially relevant studies from a total of 1611 publications identified by our search. From these, we excluded two studies that reported frequency of hypertension among patients with recurrent intracerebral haemorrhage, ${ }^{19} 20$ and two from which it was impossible to extract relevant data. ${ }^{21} 22$ This left us with 28 studies on a total of 3930 patients (2196 with deep and 1734 with lobar haemorrhage) for inclusion in our analyses. ${ }^{23-50}$ Table 1 and fig l summarise the characteristics of these studies.
Lobar haemorrhage was consistently defined as that occurring in the temporal, parietal, occipital or frontal lobes, whereas deep haemorrhage was generally defined as that arising in the basal ganglia region. Two studies reported the frequency of hypertension for deep supratentorial and posterior fossa haemorrhages together, and were included because the proportion of cases with posterior fossa haemorrhages was small (eg, 9 posterior fossa $v 90$ supratentorial deep haemorrhages in the larger of the two studies). ${ }^{32} 49$

In all, 7 studies $(\mathrm{n}=1352$ patients $)$ were population based, ${ }^{23} 25263540454613(\mathrm{n}=1856)$ used a pre-stroke defini-

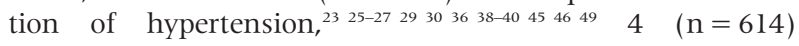
included only patients with first-ever stroke 25454650 and only $3(n=601)$ fulfilled all three of these criteria (table 1)..$^{25} 46$

Twenty studies reported the mean (or in three studies median) age, with an overall study size-weighted average (mean or median) of 59 (range 27-73) years. Fifteen studies recruited people unselected for age (weighted average 64 years), whereas five specifically recruited a younger population (generally $<45$ years, weighted average 32 years; fig $1 \mathrm{~A}$ and table 1 ). In the eight studies that reported mean or median age separately for patients with deep and lobar haemorrhage, patients with deep haemorrhage were slightly younger than those with lobar haemorrhage (weighted average $66 \vee 71$ years; table 1 ).

Six studies $23-2527450$ did not exclude people from their study population with haemorrhages from secondary causes unrelated to hypertension. The other studies had already excluded people with haemorrhages from secondary causes or provided data that allowed us to do so. The proportion of patients excluded because of a secondary cause was available from half of the studies. ${ }^{26} 282931333436-3942-444748$ It was highly variable, ranging from $6 \%$ to $73 \%$, and was generally higher in studies that specifically recruited a younger population (fig 1B, table 1). Furthermore, in studies that reported on exclusions from the deep and lobar haemorrhage groups separately, the proportion excluded was consistently highersometimes substantially so-in the group with lobar haemorrhage (table 1). No study reported the proportion of patients with deep and those with lobar haemorrhage undergoing further investigation for a secondary cause. But two studies on younger patients, in which about a third of all patients underwent catheter angiography, reported that most patients with hypertension did not have a catheter angiogram, especially if their haemorrhage was deep. ${ }^{28} 37$

Most studies used computed tomography brain imaging, but only nine reported the time from onset of symptoms to that of the scan (table 1).2324 $293338-404548$ Only a few studies mentioned any difficulty in classifying the location of the haemorrhages, and only two actually reported any unclassifiable haemorrhages. ${ }^{23} 25$ No study reported inter-rater or intrarater reliability of classification of haemorrhage location. Few studies commented on who reviewed the scans, and some classified the location based solely on information in computed tomography scan reports. Only one study reported that haemorrhage location was classified blind to the hypertension status of the patient. ${ }^{36}$

\section{Frequency of hypertension in patients with deep versus lobar haemorrhage}

The pooled OR for all studies suggested that frequency of hypertension was about twice as common in patients with deep as in those with lobar haemorrhage (OR 2.10, 95\% confidence interval (CI) 1.82 to 2.42 ; fig 2). However, we found statistically significant heterogeneity between individual studies $\left(\chi_{27}^{2}=75.4 ; p<0.001\right)$, some of which seemed to be explained by differences in study methods. For each of the three predefined methodological quality criteria, the summary OR was substantially lower for studies that fulfilled the 
Table 1 Characteristics of studies

\begin{tabular}{|c|c|c|c|c|c|c|c|c|}
\hline \multirow[b]{2}{*}{ Study* } & \multirow[b]{2}{*}{$\begin{array}{l}\text { Year of } \\
\text { publication }\end{array}$} & \multirow[b]{2}{*}{ Study population } & \multirow[b]{2}{*}{$\begin{array}{l}\text { Methodological } \\
\text { quality criteria } \\
\text { fulfilledt }\end{array}$} & \multirow[b]{2}{*}{$\begin{array}{l}\text { Exclusions due to } \\
\text { secondary causes }\end{array}$} & \multicolumn{3}{|l|}{ Total (deep/lobar) } & \multirow[b]{2}{*}{$\begin{array}{l}\text { Time to } \\
\text { scan }\end{array}$} \\
\hline & & & & & $\begin{array}{l}\% \text { of patient } \\
\text { excluded }\end{array}$ & $\begin{array}{l}\text { Number of } \\
\text { patients in } \\
\text { analyses }\end{array}$ & $\begin{array}{l}\text { Mean or } \\
\text { median age }\end{array}$ & \\
\hline \multicolumn{9}{|c|}{ Studies of populations unselected for age } \\
\hline $\begin{array}{l}\text { New Orleans, } \\
\text { USA }^{48}\end{array}$ & 1979 & $\begin{array}{l}\text { Consecutive } \\
\text { admissions to the } \\
\text { neurology } \\
\text { department }\end{array}$ & - & $\begin{array}{l}\text { AVM, blood dyscrasia, } \\
\text { coagulopathy or } \\
\text { on anticoagulants }\end{array}$ & $9 \%(3 \% / 41 \%)$ & $242(222 / 20)$ & NR & $\begin{array}{l}\text { Within } \\
8 \text { days }\end{array}$ \\
\hline $\begin{array}{l}\text { Heidelberg, } \\
\text { Germany }^{34}\end{array}$ & 1982 & $\begin{array}{l}\text { Non-consecutive } \\
\text { admissions to hospital }\end{array}$ & - & $\begin{array}{l}\mathrm{AVM}, \mathrm{CVT} \text {, or on } \\
\text { anticoagulants }\end{array}$ & $19 \%(2 \% / 37 \%)$ & $71(44 / 27)$ & 58 (NR) & NR \\
\hline $\begin{array}{l}\text { Copenhagen, } \\
\text { Denmark }^{33}\end{array}$ & 1984 & $\begin{array}{l}\text { Non-consecutive } \\
\text { admissions to } \\
\text { neurology and } \\
\text { neurosurgery departments }\end{array}$ & - & $\begin{array}{l}\mathrm{AVM} \text {, on } \\
\text { anticoagulants, alcohol } \\
\text { misuse }\end{array}$ & $25 \%(0 \% / 41 \%)$ & $36(19 / 17)$ & $54^{\star *}(\mathrm{NR})$ & $\begin{array}{l}\text { Median } \\
2 \text { days }\end{array}$ \\
\hline $\begin{array}{l}\text { Cincinnati (a), } \\
\text { USA }^{77}\end{array}$ & 1986 & $\begin{array}{l}\text { Retrospective review } \\
\text { of admissions to } 16 \\
\text { general hospitals }\end{array}$ & BP-pre & None & $0 \%$ & $124(51 / 73)$ & NR & NR \\
\hline $\begin{array}{l}\text { New York, } \\
\text { USA }^{38}\end{array}$ & 1987 & $\begin{array}{l}\text { Consecutive admissions } \\
\text { to one hospital in the } \\
\text { Bronx area of the city }\end{array}$ & BP-pre & $\begin{array}{l}\text { Blood dyscrasia, } \\
\text { vasculitis or AVM }\end{array}$ & $18 \%(11 \% / 29 \%)$ & $92(62 / 30)$ & NR & $\begin{array}{l}\text { Within } \\
24 \mathrm{~h} \text { of }\end{array}$ \\
\hline \multicolumn{9}{|l|}{ admission } \\
\hline Rome, Italy ${ }^{29}$ & 1988 & $\begin{array}{l}\text { Admissions to one } \\
\text { city-centre hospital }\end{array}$ & BP-pre & $\begin{array}{l}\text { AVM or on } \\
\text { anticoagulants }\end{array}$ & $6 \%(N R)$ & $87(56 / 31)$ & $62(N R)$ & $\begin{array}{l}\text { Mean } \\
1.6 \text { days }\end{array}$ \\
\hline $\begin{array}{l}\text { Florence, } \\
\text { Italy }^{36}\end{array}$ & 1990 & $\begin{array}{l}\text { Non-consecutive } \\
\text { patients identified } \\
\text { from the neuroradiology } \\
\text { service }\end{array}$ & BP-pre & $\begin{array}{l}\text { Blood dyscrasia, } \\
\text { on anticoagulants, } \\
\text { or AVM }\end{array}$ & $31 \%(24 \% / 48 \%)$ & $70(54 / 16)$ & $63(N R)$ & NR \\
\hline $\begin{array}{l}\text { Giessen, } \\
\text { Germany }^{44}\end{array}$ & 1990 & $\begin{array}{l}\text { Admissions to } \\
\text { neurology department } \\
\text { of one hospital }\end{array}$ & - & $\begin{array}{l}\text { AVM, } \\
\text { haemorrhagic diathesis, } \\
\text { or on warfarin }\end{array}$ & $13 \%(8 \% / 15 \%)$ & $79(57 / 22)$ & $66^{* *}(N R)$ & NR \\
\hline $\begin{array}{l}\text { Linkoping, } \\
\text { Sweden }{ }^{41}\end{array}$ & 1991 & $\begin{array}{l}\text { Consecutive admissions } \\
\text { to neurology } \\
\text { department }\end{array}$ & - & None & $0 \%$ & $182(102 / 80)$ & 65 (NR) & NR \\
\hline $\begin{array}{l}\text { Riyadh, } \\
\text { Saudi } \\
\text { Arabia }^{50}\end{array}$ & 1991 & Admissions to hospital & FES, BP-pre & NR & NR & $13(10 / 3)$ & $49(51 / 43)$ & NR \\
\hline $\mathrm{USA}^{39}$ & 1991 & $\begin{array}{l}\text { Admissions to hospitals } \\
\text { (multicentre involving } \\
4 \text { different cities) }\end{array}$ & - & $\begin{array}{l}\text { AVM, } \\
\text { coagulopathy, } \\
\text { ventricular } \\
\text { haemorrhage, multiple } \\
\text { haemorrhages or } \\
\text { on anticoagulants }\end{array}$ & $17 \%$ (NR) & $172(107 / 65)$ & $62^{* *}(59 / 68)$ & $\begin{array}{l}\text { Mean } \\
1 \text { day }\end{array}$ \\
\hline $\begin{array}{l}\text { Cincinnati } \\
\text { (b), USA }{ }^{26}\end{array}$ & 1993 & $\begin{array}{l}\text { Review of medical records } \\
\text { from } 20 \\
\text { acute-care hospitals } \\
\text { and } 5 \text { coroner's } \\
\text { offices }\end{array}$ & s P, BP-pre & $\begin{array}{l}\text { Haemorrhagic } \\
\text { infarction, AVM, } \\
\text { anticoagulants, } \\
\text { thrombolytic treatment, } \\
\text { cocaine use }\end{array}$ & $11 \%$ (NR) & $143(77 / 66)$ & NR & NR \\
\hline Oxford, UK ${ }^{25}$ & 1993 & $\begin{array}{l}\text { Community-based } \\
\text { (overlapping sources used } \\
\text { to identify cases occurring } \\
\text { in a } \\
\text { defined area) }\end{array}$ & P, FES, BP-pre & None & $0 \%$ & $42(18 / 24)$ & $71(67 / 72)$ & NR \\
\hline $\begin{array}{l}\text { Durham, } \\
\text { USA }^{30}\end{array}$ & 1994 & $\begin{array}{l}\text { Consecutive } \\
\text { admissions to one hospital }\end{array}$ & BP-pre & $\begin{array}{l}\text { Thrombocytopenia, } \\
\text { inherited coagulopathy, } \\
\text { or AVM }\end{array}$ & NR & $45(29 / 16)$ & $61(56 / 67)$ & NR \\
\hline $\begin{array}{l}\text { Essen, } \\
\text { Germany }{ }^{24}\end{array}$ & 1994 & $\begin{array}{l}\text { Admissions to } \\
\text { hospital }\end{array}$ & - & None & $0 \%$ & $300(46 / 254)$ & NR & $\begin{array}{l}\text { Within } \\
24 \mathrm{~h} \text { of }\end{array}$ \\
\hline $\begin{array}{l}\text { Perth, } \\
\text { Australiag }^{23}\end{array}$ & 1994 & $\begin{array}{l}\text { Community-based } \\
\text { (overlapping sources used } \\
\text { to identify cases occurring } \\
\text { in a } \\
\text { defined area) }\end{array}$ & P, BP-pre & None & $0 \%$ & $37(18 / 19)$ & $68(N R)$ & $\begin{array}{l}\text { Median } \\
4 \text { days }\end{array}$ \\
\hline $\begin{array}{l}\text { Massachusetts, } \\
\text { USA }^{32}\end{array}$ & 1996 & $\begin{array}{l}\text { Consecutive patients } \\
\text { aged }>50 \text { years with lobar } \\
\text { haemorrhage, } \\
\text { and with non-lobar } \\
\text { haemorrhage. Unclear } \\
\text { if both groups were } \\
\text { recruited from same } \\
\text { place and during the same } \\
\text { time period }\end{array}$ & ar & $\begin{array}{l}\text { AVM, vasculitis or } \\
\text { coagulopathy }\end{array}$ & NR & $63(18 / 45)$ & $73(69 / 75)$ & NR \\
\hline $\begin{array}{l}\text { Cologne, } \\
\text { Germany }\end{array}$ & 1997 & $\begin{array}{l}\text { Retrospective review } \\
\text { of admissions to two } \\
\text { hospitals }\end{array}$ & - & $\begin{array}{l}\text { Haemorrhagic infarcts, } \\
\text { AVM, cavernoma, } \\
\text { coagulation } \\
\text { disorders, on } \\
\text { thrombolytic or } \\
\text { anticoagulation therapy }\end{array}$ & $23 \%(10 \% / 33 \%)$ & $575(278 / 297)$ & 57 (NR) & NR \\
\hline
\end{tabular}


Table 1 Continued

\begin{tabular}{|c|c|c|c|c|c|c|c|c|}
\hline \multirow[b]{2}{*}{ Study* } & \multirow[b]{2}{*}{$\begin{array}{l}\text { Year of } \\
\text { publication }\end{array}$} & \multirow[b]{2}{*}{ Study population } & \multirow[b]{2}{*}{$\begin{array}{l}\text { Methodological } \\
\text { quality criteria } \\
\text { fulfilledt }\end{array}$} & \multirow[b]{2}{*}{$\begin{array}{l}\text { Exclusions due to } \\
\text { secondary causes }\end{array}$} & \multicolumn{3}{|l|}{ Total (deep/lobar) } & \multirow[b]{2}{*}{$\begin{array}{l}\text { Time to } \\
\text { scan }\end{array}$} \\
\hline & & & & & $\begin{array}{l}\% \text { of patient } \\
\text { excluded }\end{array}$ & $\begin{array}{l}\text { Number of } \\
\text { patients in } \\
\text { analyses }\end{array}$ & $\begin{array}{l}\text { Mean or } \\
\text { median age }\end{array}$ & \\
\hline $\begin{array}{l}\text { Victoria, } \\
\text { Australia }^{46}\end{array}$ & 1998 & $\begin{array}{l}\text { Consecutive admissions } \\
\text { to all hospitals serving } \\
\text { a defined population } \\
\text { and regular inspection } \\
\text { of coroner's reports }\end{array}$ & $P, F E S, B P$-pre & $\begin{array}{l}\text { AVM, haemorrhagic } \\
\text { transformation, } \\
\text { bleeding diathesis } \\
\text { or drug misuse }\end{array}$ & NR & $264(122 / 142)$ & 64 (NR) & NR \\
\hline $\begin{array}{l}\text { Besançon, } \\
\text { France }^{45}\end{array}$ & 2000 & $\begin{array}{l}\text { Consecutive admissions } \\
\text { to neurology, neurosurgery } \\
\text { or intensive care units } \\
\text { of the only hospital in } \\
\text { the county to which patients } \\
\text { with neurological diseases } \\
\text { are referred }\end{array}$ & P, FES, BP-pre & $\begin{array}{l}\text { Haemorrhagic } \\
\text { infarction, AVM, } \\
\text { cavernoma or on } \\
\text { thrombolytic treatment, }\end{array}$ & NR & $295(167 / 128)$ & 67 (NR) & $\begin{array}{l}\text { Mean } \\
1 \text { day }\end{array}$ \\
\hline Sweden ${ }^{40}$ & 2000 & $\begin{array}{l}\text { Community-based } \\
\text { (12 hospitals and four } \\
\text { pathology departments } \\
\text { serving a defined } \\
\text { population) }\end{array}$ & $P$ & $\begin{array}{l}\text { AVM, } \\
\text { haemorrhagic infarction }\end{array}$ & NR & $297(121 / 176)$ & $74^{* *}(72 / 75)$ & $1-2$ days \\
\hline $\begin{array}{l}\text { Cincinnati (c), } \\
\text { USA }^{49}\end{array}$ & 2002 & $\begin{array}{l}\text { Non consecutive } \\
\text { patients, identified by } \\
\text { surveillance of } \\
\text { emergency and } \\
\text { radiology departments, } \\
\text { and hospital discharge } \\
\text { diagnoses }\end{array}$ & BP-pre & $\begin{array}{l}\text { Haemorrhagic } \\
\text { infarction, AVM or } \\
\text { cavernoma }\end{array}$ & NR & $188(121 / 67)$ & $65(65 / 65)$ & NR \\
\hline Izumo, Japan ${ }^{35}$ & 2003 & $\begin{array}{l}\text { Admissions to the four } \\
\text { hospitals in the city, } \\
\text { and review of general } \\
\text { practitioner death } \\
\text { certificates }\end{array}$ & $P$ & $\begin{array}{l}\text { AVM, moyamoya } \\
\text { disease } \\
\text { haemorrhagic } \\
\text { infarction or } \\
\text { coagulation disorder }\end{array}$ & NR & $274(229 / 45)$ & $68(68 / 71)$ & NR \\
\hline \multicolumn{9}{|c|}{ Studies in younger patient populations } \\
\hline lowa, USA ${ }^{47}$ & 1987 & $\begin{array}{l}\text { Patients aged 15-45 } \\
\text { years admitted to } \\
\text { hospital }\end{array}$ & - & $\begin{array}{l}\text { AVM, haemorrhage } \\
\text { as a result of drug } \\
\text { or alcohol misuse, } \\
\text { SLE, moyamoya, } \\
\text { cryoglobulinaemia, } \\
\text { or preeclampsia }\end{array}$ & $58 \%(41 \% / 67 \%)$ & $22(10 / 12)$ & 31 (NR) & NR \\
\hline Dijon, France ${ }^{31}$ & 1991 & $\begin{array}{l}\text { Patients aged }<45 \\
\text { years admitted to } \\
\text { neurosurgery, } \\
\text { neurology and } \\
\text { rehabilitation departments } \\
\text { of the } \\
\text { city's university } \\
\text { hospital }\end{array}$ & - & $\begin{array}{l}\text { AVM, cerebral } \\
\text { vein thrombosis, } \\
\text { SLE, endocarditis, } \\
\text { leukaemia or on } \\
\text { anticoagulants }\end{array}$ & $59 \%(27 \% / 76 \%)$ & $12(8 / 5)$ & 33 (NR) & NR \\
\hline $\begin{array}{l}\text { Mexico City, } \\
\text { Mexico }^{43}\end{array}$ & 1991 & $\begin{array}{l}\text { Consecutive admission } \\
\text { of patients aged }<40 \text { years } \\
\text { to stroke } \\
\text { unit }\end{array}$ & - & $\begin{array}{l}\text { AVM, cavernous } \\
\text { angioma, CVT, drug } \\
\text { use, toxaemia or } \\
\text { other known causes }\end{array}$ & $75 \%(49 \% / 85 \%)$ & $38(22 / 16)$ & 27 (NR) & NR \\
\hline $\begin{array}{l}\text { Tainan Taiwan } \\
\left(\text { a) }{ }^{37}\right.\end{array}$ & 1997 & $\begin{array}{l}\text { Patients aged } 14-40 \text { years - } \\
\text { admitted to hospital }\end{array}$ & & $\begin{array}{l}\text { AVM, drug misuse, } \\
\text { blood dyscrasia, } \\
\text { alcohol misuse, SLE, } \\
\text { moyamoya or } \\
\text { infective endocarditis }\end{array}$ & $35 \%(24 \% / 50 \%)$ & $40(26 / 14)$ & 34 (NR) & NR \\
\hline $\begin{array}{l}\text { Kaohsiung, } \\
\text { Taiwan }(b)^{28}\end{array}$ & 1999 & $\begin{array}{l}\text { Patients aged } 15-44 \text { years - } \\
\text { admitted to hospital }\end{array}$ & & $\begin{array}{l}\text { AVM, blood } \\
\text { dyscrasia and } \\
\text { "other rare causes" } \\
\text { (including alcohol } \\
\text { and drug misuse, } \\
\text { uraemia, etc). We could } \\
\text { not exclude } 4 \text { patients } \\
\text { with fumours. }\end{array}$ & $33 \%(12 \% / 53 \%)$ & $126(102 / 24)$ & 36 (NR) & NR \\
\hline
\end{tabular}

AVM, arteriovenous malformation; CVT, cerebral venous thrombosis; NR, not reported; SLE, systemic lupus erythematosus.

*Studies are ordered first according to whether they included mixed-age or younger populations, and then by year of publication.

$\dagger$; BP-pre, definition of hypertension based on pre-stroke blood pressure (not post-stroke or combination of pre-stroke and post-stroke blood pressure); FES, firstever stroke only; $P$, population based.

$\ddagger$ Percentage of all deep and lobar supratentorial haemorrhages excluded because of secondary causes (except for Rome, Cincinnati (b) and USA, where the percentage excluded is calculated with all haemorrhages, including those in the posterior fossa, as the denominator).

§A total of 3930 patients with haemorrhage were included in the analyses, 2196 of whom had a deep haemorrhage.

- Mean or median (indicated by ${ }^{* *}$ ) age of total population with intracerebral haemorrhage (including those with posterior fossa haemorrhage). In cases where age was reported as the number of patients within various age bands, mean age was derived by assigning the middle value of each age band to the number of patients included. 

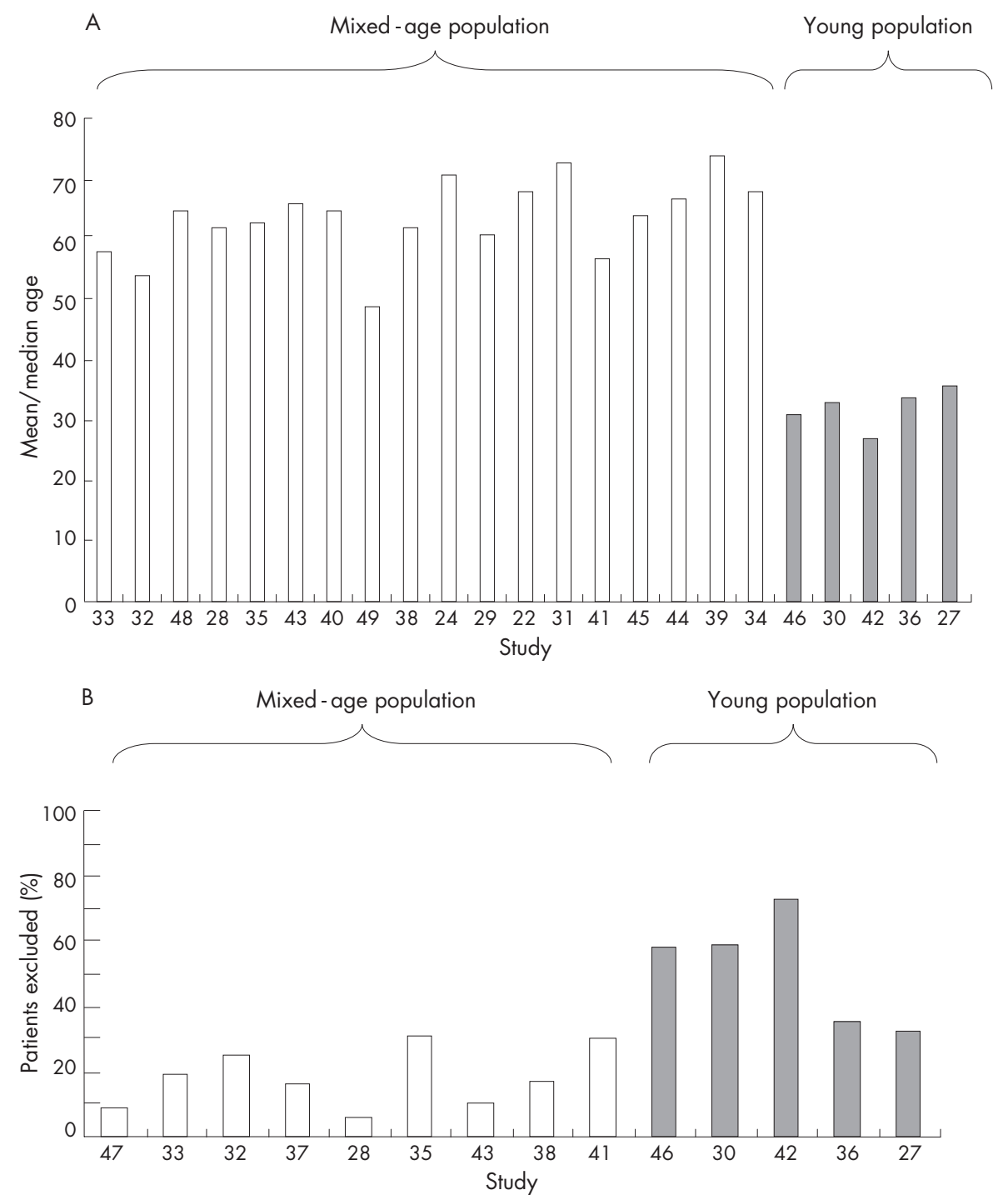

Figure 1 (A) Mean or median age of study populations. (B) Proportion of patients excluded because of haemorrhage from a secondary cause, such as intracranial vascular malformation, blood dyscrasia or anticoagulant treatment.

criterion than for those that did not, with significant heterogeneity between the two groups of studies in each case (fig 3). The pooled OR for the three studies (601 patients) meeting all three criteria (OR 1.50, 95\% CI 1.09 to 2.07) suggested a smaller but still statistically significant excess of hypertension in deep versus lobar haemorrhage. The OR for these methodologically more rigorous studies was substantially lower than that for the remaining studies (OR 2.27, $95 \%$ CI 1.94 to 2.66), with significant heterogeneity between the two groups (fig 3).

The pooled OR for studies that included only younger patients (OR 12.32, 95\% CI 6.13 to 24.77) was far larger than for studies that recruited a population unselected for age (OR $1.91,95 \%$ CI 1.65 to 2.21 ).

\section{DISCUSSION}

The pooled result from all the studies we analysed suggested that hypertension was twice as common a risk factor for patients with deep haemorrhage than with lobar haemorrhage without an identified secondary cause. We found an excess of hypertension among patients with deep haemorrhage in the methodologically more rigorous studies, albeit smaller and statistically less certain. As only three studies actually met all of our rather modest criteria for methodological quality, this summary estimate is based on quite small numbers of patients $(601$, less than one sixth of the total in all studies included). The differences between subgroups in the various sensitivity analyses are striking and emphasise the effect of study methods on the results.

We could not quantify the effect of the additional potential sources of bias that we considered, but these are also likely to have affected the results. Firstly, some misclassification of haemorrhage location must surely have occurred, yet only two studies acknowledged this, none reported reliability of the classification of the haemorrhage location and only one mentioned that scans were reported blind to hypertension status. As the concept of deep hypertensive haemorrhage is entrenched in clinical teaching and practice, the knowledge of a patient's hypertension status may have influenced the classification of haemorrhage location and may have generated a spurious association between hypertension and deep versus lobar haemorrhage. This may be particularly true in the classification of large haemorrhages, for which the location of the original bleeding source may be uncertain. Many such corticosubcortical haemorrhages are thought to originate from the basal ganglia, but evidence for this is limited. ${ }^{15}$ 


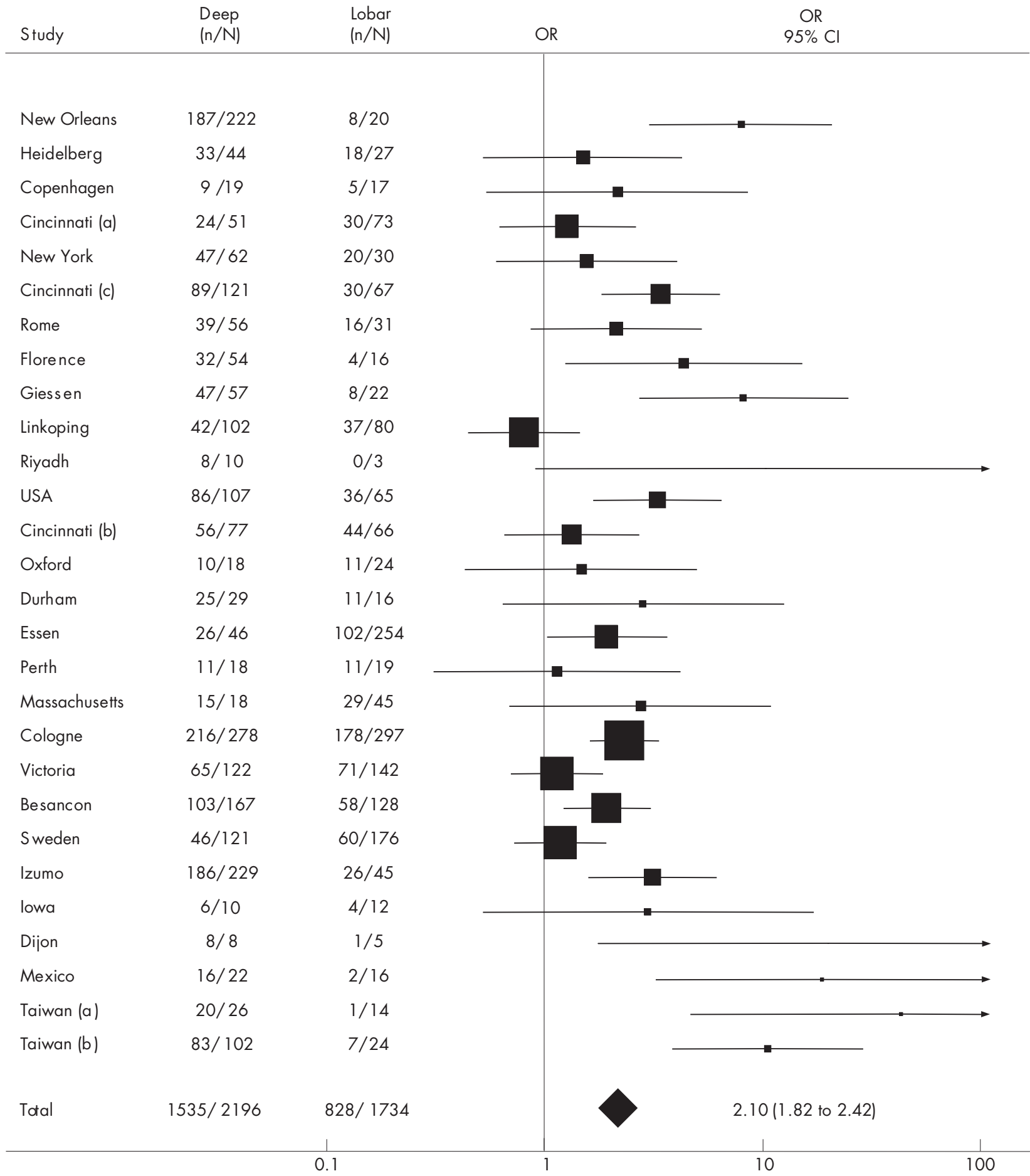

Figure 2 Odds ratios (ORs) for hypertension in patients with deep versus lobar haemorrhage. The OR for each study is shown as a square, its size denoting the statistical weight of the study. Horizontal lines represent $95 \%$ confidence intervals (Cls). The diamond represents the pooled OR, with the $95 \% \mathrm{Cl}$ represented by the width of the diamond. Studies are ordered first according to whether they included mixed-age or younger populations, and then by year of publication. $N$, total number of patients; $n$, number of patients with hypertension. Heterogeneity between studies: $\chi^{2} 27=75.44$; $\mathrm{p}<0.001$.

Secondly, few studies reported on the timing of the brain scan relative to the onset of symptoms. Many may have included some patients with haemorrhagic transformation of a cerebral infarct, although it is difficult to know just how this may have affected our results.

Thirdly, investigation bias is likely to have affected the results of these studies to a variable degree. The study populations included in our analyses depended on the extent of patient investigation, which may well have differed between groups with deep and lobar haemorrhage and according to age. The available data showed a larger proportion of exclusions from younger study populations than from those unselected for age, and from groups of patients with lobar rather than deep haemorrhage. This could be because of real differences in the proportions with an underlying secondary cause, higher rates of investigation on 


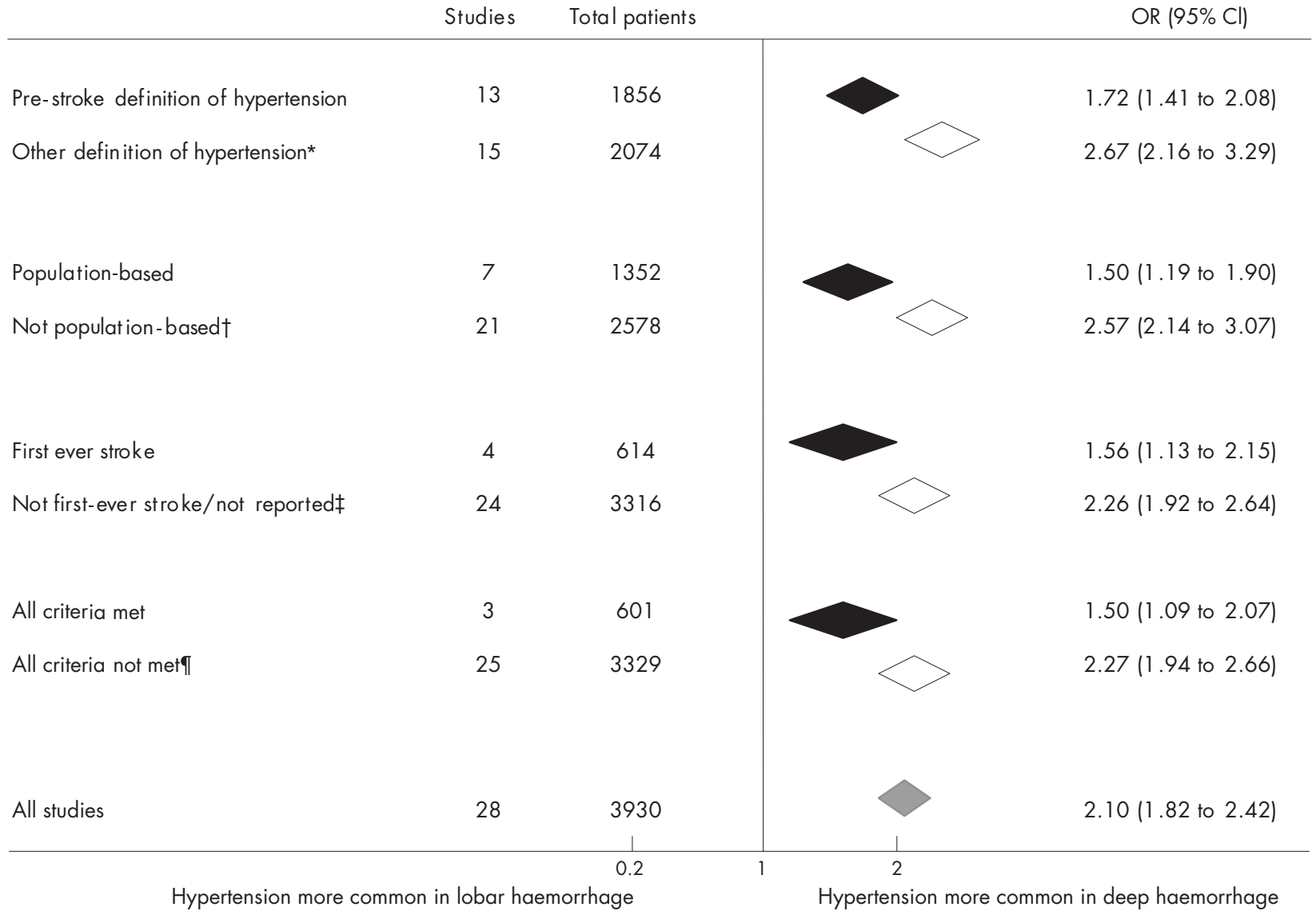

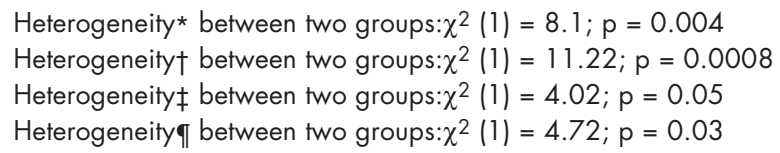

Figure 3 Sensitivity subgroup analyses using pre-defined methodological quality criteria. The black diamonds represent the summary odds ratios (ORs) for studies meeting each criterion, the white diamonds represent the summary ORs for studies not meeting each criterion and the grey diamond represents the pooled OR for all 28 studies. $\mathrm{Cl}$, confidence interval.

younger patients and on those with lobar haemorrhage, or both. Some support for differential investigation bias being part of the explanation comes from two studies on younger patients that reported lower rates of catheter angiography among patients with hypertension and deep haemorrhage, ${ }^{28} 37$ as well as from the (admittedly anecdotal) observation that, in clinical practice, a non-hypertensive structural cause is less often considered and sought if a history of hypertension and brain imaging shows a deep rather than a lobar haemorrhage. Some of the excess of hypertension found among patients with deep haemorrhage may therefore be accounted for by differential investigation, resulting in secondary causes remaining undetected among those having deep haemorrhage with coincidental hypertension.

We may expect studies on younger patients to be particularly useful in that these patients should be more extensively investigated and thus allow a more accurate assessment of the contribution of hypertension to deep and lobar haemorrhages that have no identifiable secondary cause. We found that the frequency of hypertension in patients with deep versus lobar haemorrhage was much higher in studies on only young patients than in those studies that did not select on age. This result, however, is difficult to interpret, as the number of patients included in the studies on younger patients $(n=238)$ was very small, making the results imprecise. Furthermore, none of these studies met any of our predefined methodological quality criteria, and the result could reflect greater investigation bias in younger patients. None the less, the apparently more extreme excess of hypertension in younger patients with deep versus lobar haemorrhages is an interesting finding that deserves further study.

Given that cerebral amyloid angiopathy is thought to be particularly important in elderly people, it would have been interesting to assess the effect of age on the results of studies in which patients were unselected for age. Only two studies, however, reported a frequency of hypertension by age group; they used different age cut-offs and the numbers of patients were too small to allow any meaningful analyses. This is a limitation of our systematic review and further large studies that allow agespecific analyses are required to explore this issue.

Our analyses have considered the contribution of chronically raised blood pressure to lobar and deep haemorrhage. Intracerebral haemorrhage may also arise as a result of acutely raised blood pressure, particularly in previously normotensive people. Such acute sudden rises in blood pressure may be of more importance for deep than for lobar haemorrhage, but this would be particularly difficult to study in humans, because it is impossible to distinguish raised blood pressure arising as a result of the intracerebral haemorrhage from sudden raised blood pressure precipitating the haemorrhage. Although there are reports in the literature of instances where intracerebral haemorrhage was assumed 
to be the result of acutely raised blood pressure, no clear evidence indicates that this occurs more often in patients with deep than with lobar haemorrhage. ${ }^{151}$

In summary, pooled results from observational studies suggest that hypertension is more frequently a risk factor for deep than for lobar haemorrhage, perhaps particularly in younger age groups. These findings are, however, heavily influenced by studies with less robust methods. In the methodologically more rigorous studies, we found a smaller, but still statistically significant, excess of hypertension among patients with deep haemorrhage. This may, however, be accounted for by additional, unquantified sources of bias. Further large, methodologically robust studies are needed to determine accurately the relative contribution of hypertension to deep and lobar haemorrhage in different age groups. After the exclusion of secondary causes, raised blood pressure may make an important contribution to the arterial pathologies underlying lobar haemorrhages-for example, cerebral amyloid angiopathy-as well as to those leading to rupture of small, deep, penetrating arteries. Thus, the terms hypertensive haemorrhage and deep haemorrhage should not be considered synonymous, as this implies that all deep haemorrhages are attributable solely to hypertension. This may cause some patients with deep haemorrhages routinely to be excluded from further investigation on potentially treatable non-hypertensive causes (such as arteriovenous malformations), especially if they are elderly.

\section{ACKNOWLEDGEMENTS}

We thank Professors Charles Warlow, Martin Dennis, Joanna Wardlaw and Dr Rustam Al-Shahi for their comments on an earlier version of this manuscript, and Brenda Thomas for her assistance with designing the electronic search strategy.

\section{Authors' affiliations}

C A Jackson, C L M Sudlow, Division of Clinical Neurosciences, University of Edinburgh, Western General Hospital, Edinburgh, UK

Funding: CAJ and CLMS were funded by the Wellcome Trust, UK, which had no role in the design, analysis or interpretation of the results this study, in the writing of the paper or in the decision to submit it for publication.

Competing interests: None.

Author contributions: CAJ and CLMS both had the idea for and designed the study. CAJ ran the search strategy and carried out the initial identification of potentially relevant studies, with the final selection made by both authors in discussion. CAJ extracted data from the studies and carried out the analyses. CLMS checked the data and refined the analyses. CAJ and CLMS wrote and revised the paper.

\section{REFERENCES}

1 Warlow C, Dennis M, van Gijn J, et al. What caused this intracerebral haemorrhage? In: Sandercock PAG, Hankey, GJ van Gijn J, et al, eds. Stroke: a practical guide to management. 2nd edn. Oxford: Blackwell Sciences, 2001:339-75.

2 Thrift A, McNeil J, Forbes A, et al. Risk factors for cerebral haemorrhage in the era of well-controlled hypertension. Melbourne Risk Factor Study (MERFS) Group. Stroke 1996;27:2020-5

3 Saloheimo P, Juvela S, Hillbom M. Use of aspirin, epistaxis, and untreated hypertension as risk factors for primary intracerebral haemorrhage in middleaged and elderly people. Stroke 2001;32:399-404.

4 Eastern Stroke and Coronary Heart Disease Collaborative Research Group. Blood pressure, cholesterol, and stroke in Eastern Asia. Lancet 1998;352:1801-7.

5 Juvela S, Hillbom M, Palomäki $\mathrm{H}$. Risk factors for spontaneous intracerebral haemorrhage. Stroke 1995;26:1558-64.

6 Prospective Studies Collaboration. Age-specific relevance of usual blood pressure to vascular mortality: a meta-analysis of individual data for one million adults in 61 prospective studies. Lancet 2002;360:1903-13.

7 Woo D, Haverbusch M, Sekar P, et al. Effect of untreated hypertension on haemorrhagic stroke. Stroke 2004;35:1703-8.

8 Song Y-M, Sung J, Lawlor D, et al. Blood pressure, haemorrhagic stroke, and ischaemic stroke: the Korean national prospective occupational cohort study. BMJ 2004;328:324-5.
9 Cole FM, Yates PO. Intracerebral microaneurysms and small cerebrovascular lesions. Brain 1967;90:759-67.

10 Cole FM, Yates PO. The occurrence and significance of intracerebral microaneurysms. J Pathol Bacteriol 1967;93:393-411.

11 Fisher CM. Pathological observations in hypertensive cerebral haemorrhage. J Neuropathol Exp Neurol 1971;30:536-50.

12 Fisher CM. Cerebral miliary aneurysms in hypertension. Am J Pathol 1972;66:313-30.

13 Russell RRW. Observations on intracerebral aneurysms. Brain 1963;86:425-42.

14 Rosenblum WI. Miliary aneurysms and "fibrinoid" degeneration of cerebral blood vessels. Hum Pathol 1977;8:133-9.

15 Kase C, Mohr JP, Caplan LR. Intracerebral haemorrhage. In: Mohr JP, Choi DW, Grotta JC, et al, eds. Stroke: pathophysiology, diagnosis and management. Philadelphia: Churchill Livingstone, 2004:327-75.

16 Labovitz DL, Sacco RL. Intracerebral hemorrhage: update. Curr Opin Neurol $2001 ; 14: 103-8$.

17 Sacco RL. Lobar intracerebral hemorrhage. N Engl J Med 2000;342:276-9.

18 Cochrane Collaboration. Cochrane Revman software V.4.2. 2003. http:// www.cc-ims.net/RevMan.

19 Neau JP, Ingrand P, Couderq C, et al. Recurrent intracerebral hemorrhage. Neurology 1997;49:106-13.

20 Passero S, Burgalassi L, D'Andrea $\mathrm{P}$, et al. Recurrence of bleeding in patients with primary intracerebral hemorrhage. Stroke 1995;26:1189-92.

21 Qureshi AI, Suri MAK, Safdar K, et al. Intracerebral haemorrhage in blacks. Stroke 1997;28:961-4.

22 Passero S, Reale F, Ciacci G, et al. Differing temporal patterns of onset in subgroups of patients with intracerebral haemorrhage. Stroke 2000;31:1538-44

23 Anderson CS, Chakera TM, Stewart-Wynne EG, et al. Spectrum of primary intracerebral haemorrhage in Perth, Western Australia, 1989-90: incidence and outcome. J Neurol Neurosurg Psychiatry 1994:57:936-40.

24 Berlit P, Tornow K. Outcome of intracerebral haemorrhage: clinical and CT findings in 326 patients. Eur J Neurol 1994;1:29-34.

25 Boonyakarnkul S, Dennis $M$, Sandercock P, et al. Primary intracerebral haemorrhage in the Oxfordshire Community Stroke Project. Cerebrovasc Dis 1993;3:343-9

26 Broderick J, Brott T, Tomsick T, et al. Lobar hemorrhage in the elderly. The undiminishing importance of hypertension. Stroke 1993;24:49-51.

27 Brott T, Thalinger K, Hertzberg V. Hypertension as a risk factor for spontaneous intracerebral haemorrhage. Stroke 1986;17:1078-83.

28 Chen C-H, Lai M-L. Nontraumatic intracerebral haemorrhage in young adults: analysis of 214 cases. Acta Neurol 1999;8:96-101.

29 Fieschi C, Carolei A, Fiorelli $M$, et al. Changing prognosis of primary intracerebral haemorrhage: results of a clinical and computed tomographic follow-up study of 104 patients. Stroke 1988;19:192-5.

30 Graffagnino C, Herbstreith $M H$, Roses $A D$, et al. A molecular genetic study of intracerebral hemorrhage. Arch Neurol 1994;51:981-4

31 Gras P, Arveux P, Giroud M, et al. Spontaneous intracerebral hemorrhages in young patients. Study of 33 cases. Rev Neurol 1991;147:653-7.

32 Greenberg SM, Briggs ME, Hyman BT, et al. Apolipoprotein E epsilon 4 is associated with the presence and earlier onset of hemorrhage in cerebral amyloid angiopathy. Stroke 1996;27:1333-7.

33 Helweg-Larson S, Sommer W, Strange P, et al. Prognosis for patients treated conservatively for spontaneous intracerebral haematomas. Stroke 1984; 15: 1045-8.

34 Herold S, Kummer Rv, Jaeger Ch. Follow-up of spontaneous intracerebral haemorrhage by computed tomography. J Neurol 1982;228:267-76.

35 Inagawa T, Ohbayashi N, Takechi A, et al. Primary intracerebral hemorrhage in Izumo City, Japan: incidence rates and outcome in relation to the site of hemorrhage. Neurosurgery 2003;53:1283-97.

36 Inzitari D, Giordano GP, Ancona AL, et al. Leukoaraiosis, intracerebral hemorrhage, and arterial hypertension. Stroke 1990;21:1419-23.

37 Lin CL, Howng SL. Nontraumatic intracerebral hemorrhage in young adult. Kaohsiung J Med Sci 1997; 13:237-42.

38 Lipton RB, Berger AR, Lesser ML, et al. Lobar vs thalamic and basal ganglion hemorrhage: clinical and radiographic features. J Neurol 1987;234:86-90.

39 Massaro AR, Sacco RL, Mohr JP, et al. Clinical discriminators of lobar and deep hemorrhages: the Stroke Data Bank. Neurology 1991;41:1881-5.

40 Nilsson OG, Lindgren A, Stahl N, et al. Incidence of intracerebral and subarachnoid haemorrhage in southern Sweden. J Neurol Neurosurg Psychiatry 2000:69:601-7.

41 Radberg JA, Olsson JE, Radberg CT. Prognostic parameters in spontaneous intracerebral hematomas with special reference to anticoagulant treatment. Stroke 1991;22:571-6.

42 Rosenow F, Hojer Ch, Meyer-Lohmann Ch, et al. Spontaneous intracerebral haemorrhage: prognostic factors in 896 cases. Acta Neurol Scand 1997;96:174-82.

43 Ruiz-Sandoval JL, Cantu C, Barinagarrementeria F. Intracerebral hemorrhage in young people: analysis of risk factors, location, causes, and prognosis. Stroke 1999:30:537-41.

44 Schutz H, Bodeker RH, Damian M, et al. Age-related spontaneous intracerebral hematoma in a German community. Stroke 1990;21:1412-8.

45 Tatu L, Moulin T, El Mohamad R, et al. Primary intracerebral hemorrhages in the Besancon stroke registry. Initial clinical and CT findings, early course and 30-day outcome in 350 patients. Eur Neurol 2000;43:209-14.

46 Thrift A, McNeil J, Forbes A, et al. Three important subgroups of hypertensive persons at greater risk of intracerebral haemorrhage. Hypertension 1998;31:1223-9.

47 Toffol GJ, Biller J, Adams HP Jr. Nontraumatic intracerebral hemorrhage in young adults. Arch Neurol 1987;44:483-5. 
48 Weisberg LA. Computerized tomography in intracranial hemorrhage. Arch Neurol 1979;36:422-6

49 Woo D, Sauerbeck LR, Kissela BM, et al. Genetic and environmental risk factors for intracerebral hemorrhage: preliminary results of a populationbased study. Stroke 2002;33:1190-5.

50 Yaqub BA, Shamena AR, Kolawole TM, et al. Cerebrovascular disease in Saudi Arabia. Stroke 1991;22:1173-6.

51 Caplan L. Intracerebral haemorrhage revisited. Neurology 1988;38:624-7.

\section{APPENDIX}

\section{Medline search}

1. exp intracranial hemorrhages/

2. ( (brain\$ or cerebral or intracranial or intracerebral) adj5 (haemorrhage\$ or hemorrhage\$ or bleed\$)).tw.

3. ich.tw.

4. exp intracranial hemorrhages/ or ( (brain\$ or cerebral or intracranial or intracerebral) adj5 (haemorrhage $\$$ or hemorrhage\$ or bleed\$)).tw. or ich.tw
5. (lobar or deep or subcortical or sub-cortical).tw.

6. exp cerebral amyloid angiopathy/

7. cerebral amyloid angiopath\$.tw.

8. exp cerebral amyloid angiopathy/ or cerebral amyloid angiopath\$.tw.

9. (lobar or deep or subcortical or sub-cortical).tw. or exp cerebral amyloid angiopathy/ or cerebral amyloid angiopath\$.tw.

10. exp intracranial hemorrhages/ or ( (brain\$ or cerebral or intracranial or intracerebral) adj5 (haemorrhage\$ or hemorrhage\$ or bleed\$)).tw. or ich.tw and (lobar or deep or subcortical or sub-cortical).tw. or exp cerebral amyloid angiopathy/ or cerebral amyloid angiopath\$.tw.

A similar search was used for Embase.

\section{Clinical Evidence-Call for contributors}

Clinical Evidence is a regularly updated evidence-based journal available worldwide both as a paper version and on the internet. Clinical Evidence needs to recruit a number of new contributors. Contributors are healthcare professionals or epidemiologists with experience in evidence-based medicine and the ability to write in a concise and structured way.

Areas for which we are currently seeking contributors:

- Pregnancy and childbirth

- Endocrine disorders

- Palliative care

- Tropical diseases

We are also looking for contributors for existing topics. For full details on what these topics are please visit www.clinicalevidence.com/ceweb/contribute/index.jsp

However, we are always looking for others, so do not let this list discourage you.

Being a contributor involves:

- Selecting from a validated, screened search (performed by in-house Information Specialists) epidemiologically sound studies for inclusion.

- Documenting your decisions about which studies to include on an inclusion and exclusion form, which we keep on file.

- Writing the text to a highly structured template (about 1500-3000 words), using evidence from the final studies chosen, within 8-10 weeks of receiving the literature search.

- Working with Clinical Evidence editors to ensure that the final text meets epidemiological and style standards.

- Updating the text every 12 months using any new, sound evidence that becomes available. The Clinical Evidence in-house team will conduct the searches for contributors; your task is simply to filter out high quality studies and incorporate them in the existing text.

If you would like to become a contributor for Clinical Evidence or require more information about what this involves please send your contact details and a copy of your CV, clearly stating the clinical area you are interested in, to CECommissioning@bmigroup.com.

\section{Call for peer reviewers}

Clinical Evidence also needs to recruit a number of new peer reviewers specifically with an interest in the clinical areas stated above, and also others related to general practice. Peer reviewers are healthcare professionals or epidemiologists with experience in evidence-based medicine. As a peer reviewer you would be asked for your views on the clinical relevance, validity, and accessibility of specific topics within the journal, and their usefulness to the intended audience (international generalists and healthcare professionals, possibly with limited statistical knowledge). Topics are usually 1500-3000 words in length and we would ask you to review between 2-5 topics per year. The peer review process takes place throughout the year, and out turnaround time for each review is ideally 10-14 days. If you are interested in becoming a peer reviewer for Clinical Evidence, please complete the peer review questionnaire at www.clinicalevidence.com/ceweb/contribute/peerreviewer.jsp 